\title{
Effect of intercropping of corn and soybean on dry matter yield and nutritive value of forage corn
}

\begin{abstract}
Cereal-based forage production could be considered to have potential to supply great deal of energy-rich feed in animal diets. Experiment was conducted to evaluate effect of cornsoybean combinations of 75:25, 50:50 and 25:75 in addition to monocrops of corn and soybean to detremine forage dry matter (DM) yield and quality in corn-soybean intercropping. The crop combination ratio had significant effects on dry matter yield and nutritive quality of forage. The ratio of 75:25 and 50:50 recorded DM yields similar to those of monocropped corn $(14.77 \mathrm{t} / \mathrm{ha})$. Forage quality in terms of crude protein (CP) (75:25 ratio $12.75 \%, 50: 50$ ratio $13.73 \%$ and $25: 75$ ratio $14.68 \%$ ) was improved by intercropping due to higher nitrogen availability for corn in intercropping compared with its sole crop $(10.83 \%$ $\mathrm{CP}$ ). Increase ratio of corn in corn-soybean mixture, negatively affectd neutral detergent fiber (NDF), acid detergent fiber (ADF) of forage and declined with increasing ratio of soybean plants. Combination ratio of 50:50 gave higher protein yield $(1886.45 \mathrm{~kg} / \mathrm{ha})$ than other crop combination ratio. Among all the combination ratios, the 50:50 corn-soybean ratio was the optimum giving highest forage yield, protein content as well as protein yield.
\end{abstract}

Keyword: Corn-legume forage; Intercropping; Nutritive quality; NIRS; Protein yield 